\title{
Ambivalent Sexism, Attribution of Blame to the Victim and Perceptions about Victims of Violence in Relationships
}

\author{
Daniar Bella Amandasari and Margaretha \\ Faculty of Psychology \\ Universitas Airlangga
}

\begin{abstract}
Female relationship violence (RV) victims often do not get help and are seen as in a negative light, even being subjected to victim-blaming, because they are triggered by sexism. Sexism, as a traditional gender perspective, puts more emphasis on the position of women; and now has an ambivalent quality, with the emergence of two forms of sexism, namely: hostile sexism (the viewing of women in a negative way, and as incompetent) and benevolent sexism (women are being considered to be weak, and so they need protection). This study aims to determine the effects of ambivalent sexism, and attributions of blame to the victims, for the perception of RV victims. The survey, conducted with on 299 students, from four high-schools in Sidoarjo, East Java, for measuring ambivalent sexism, with the Extended Ambivalent Sexism Inventory (EASI), and; the Domestic Violence Blame Scale (DVBS) to measure the attribution of blame to the victim. The perception of RV victims was measured by using a vignette which contained photos and stories about a female RV victim. Regression analysis found that benevolent sexism had a positive effect on the perceptions of victims $(\beta=0.19, p<.05)$. Individuals demonstrating high benevolent sexism will tend to view KDP RV victims as traditional women.
\end{abstract}

Keywords: attribution of blame to the victim, relationship violence, perceptions about victims, ambivalent sexism

\begin{abstract}
Perempuan korban kekerasan dalam pacaran sering tidak mendapatkan bantuan dan dipandang secara negatif, bahkan disalahkan, karena adanya pengaruh dari seksisme. Seksisme, sebagai persepsi gender tradisional, lebih menekankan pada posisi perempuan; dan sekarang memiliki kualitas ambivalen, dengan munculnya dua bentuk seksisme, yaitu: seksisme agresif (melihat perempuan secara negatif dan tidak kompeten) dan seksisme baik (perempuan dipandang lemah dan perlu perlindungan). Studi ini bertujuan untuk menentukan efek dari seksisme ambivalen, dan atribusi kesalahan korban, dalam persepsi korban kekerasan dalam pacaran. Survei dilakukan pada 299 murid sekolah menengah tinggi di Sidoarjo, Jawa Timur, dan untuk mengukur seksisme ambivalen digunakan Extended Ambivalent Sexism Inventory (EASI) dan Domestic Violence Blame Scale (DVBS) untuk mengukur atribusi kesalahan korban. Persepsi korban diukur dengan alat bantu yang terdiri dari foto dan cerita mengenai korban kekerasan dalam pacaran. Analisis regresi menemukan bahwa seksisme baik memiliki efek positif pada persepsi korban $(\beta=0.19, p<.05)$. Individu dengan seksisme baik tinggi cenderung memandang korban kekerasan dalam pacaran sebagai perempuan tradisional.
\end{abstract}

Kata kunci: atribusi kesalahan korban, kekerasan dalam pacaran, persepsi mengenai korban, seksisme ambivalen

Relationship violence (RV) is a general form of violence against women, referring to conduct by partners, or ex-partners, which has a physical, sexual or psychological impact, such as physical aggression, forced sex, psychological torture, and controlling behavior (World Health Organization, 2017), such as

Correspondence concerning this article should be addressed Daniar Bella Amandasari, Faculty of Psychology, Universitas Airlangga. Jalan Airlangga No. 4-6, Surabaya 60115. E-mail: daniarbellaa@gmail.com efforts to control or dominate the partner, in a physical, sexual or psychological fashion, which may endanger the partner (Wekerle \& Wolfe, 1999). Violence in relationships may arise when the environment of the perpetrator supports the presence of violence against his partner, such as is found in middle and lower economic situations, a life far distant from cities, and limits to educational and employment opportunities (Waltermaurer, 2012). 
In 2014 , there were 1,748 cases of relationship violence (Komnas Perempuan, 2014). In 2016, there was an escalation in the number of cases, with 2,734 cases being recorded (Komnas Perempuan, 2016), whilst in 2017, there were 2,171 cases of relationship violence (Komnas Perempuan, 2017). With the existence of this data concerning the cases of violence which have occurred, society may have a perception concerning the victims of violence. This perception concerning the victims of RV is the judgement or impression held by people, based upon the information received (Nelson, 2006). Fiske et al. (2002) divided women into sub-types, on the basis of their warmth and competence, as traditional and non-traditional women. The perception of victims of RV as traditional women is an impression which has emerged among observers, that the victims are women who show a pro-social attitude, and are capable of performing their roles as good women (as wives and mothers) (Fiske et al., 2002). Conversely, the perception that the victims of RV are non-traditional women is an impression which has emerged amongst observers, that the victims are women showing a competent attitude in agentic abilities (Fiske et al., 2002).

Victims of relationship violence tend more to be blamed, compared to victims of domestic violence (Yamawaki et al., 2012). Being in a relationship is considered to be less serious, compared with marriage. In a relationship, a person may easily sever the relationship, as in a relationship there are no legal ties (Yamawaki et al., 2012). This fact can have an impact on the assistance which may be given to the victim. The authorities in the criminal legal system, such as the police and judges, will have a perception which may determine their findings regarding the perpetrator of the violence. The public, which has attitudes and perceptions concerning violence within intimate relationships, may strengthen and emphasize various types of misunderstanding concerning violence in intimate relationships. This may have an impact on the overlooking of cases of violence, particularly violence in interpersonal relations. This can also have an unfortunate impact on the victim, because those in the environment may tend to blame the victim instead (Witte, Schroeder, \& Lohr, 2006). Glick and Fiske (1996) also add that a sexist attitude related to the person suffering the violence will have a negative impact on the victim.

Sexism is negative attitudes and conduct towards someone, on the basis of his or her gender. Sexism is a form of prejudice (Nelson, 2006). Glick and Fiske (1996) have devised one construct of this sexism, call- ed ambivalent sexism, which has two opposing values, but which are similar. This concept comprises two sexist values, hostile sexism and benevolent sexism. Sexism contains not only 'antipathy towards women, but also prejudice and stereotyping, which may seem to be positive.

People with high ambivalent sexism tend to blame the victims and minimalize incidents of violence committed by people they know (Abrams et al., 2003). Yamawaki (2007) discovered that ambivalent sexism is a significant moderator of the perceptions of a person. Yamawaki (2007) added that a person high in hostile sexism tends to deny the existence of social damage suffered by the victim, and ignore the level of seriousness of what has occurred. This takes place because a woman is viewed as someone who often exaggerates problems, is easily offended, and seeks advantage or power by using her sexuality, whereas a person with benevolent sexism tends to attribute the blame to the victim of rape by her partner, because the victim is considered to have transgressed traditional gender roles, so that the victim needs no protection (Frese, Moya, \& Megias, 2004; Schuller \& Wall, 1998; Viki \& Abrams, 2002; Yamawaki, 2007).

Gaunt (2013) also discovered that hostile sexism is a predictor of negative perceptions towards a woman who works, and that benevolent sexism is a predictor of negative perceptions towards a woman caring for a child. This indicates that a woman who transgresses her gender role, such as a career woman, will be viewed negatively by people with hostile sexism, because they view such women as threatening male roles. When a woman transgresses traditional gender roles, she will be categorized as one of a group who are disliked, and who are considered not to require protection from males (Glick \& Fiske, 2001; Sakalh, 2001; Yakushko, 2005; Yamawaki, Ostenson, \& Brown, 2009), whereas women who rear children, or do not transgress gender roles, will be viewed positively by someone with benevolent sexism.

The development of the theory of ambivalent sexism was conducted by Mikolajczak and Pietrzak (2015). They criticized the theory and scales of ambivalent sexism as developed by Glick and Fiske (1996), because the basis of the compilation of that theory and scale of ambivalent sexism utilized a sample which was not universal. Because of that shortcoming, they developed the Ambivalent Sexism Inventory (ASI) into the Extended Ambivalent Sexism Inventory (EASI), by adding three concepts to benevolent sexism, outside protective paternalism, mutually complementary gender differences, and heterosexual intimacy; these 
being the concepts of motherhood, beauty and ingenuity, which women have.

The attribution of fault to the victim may also be called victim-blaming. The attribution of fault to the victim is an attribution error. Attribution of fault to the victim is a repressive act, which occurs when the victim of a criminal act or misfortune is considered to be responsible for that which she has undergone (Schoellkopf, 2012). The researchers, Abrams et al. (2003), showed that there is a significant connection between attribution of fault to the victim, and the perception that the victim has engaged in unsuitable behavior, and this can have an impact on the conduct of observers and their assistance to victims of domestic violence. Victims of rape in relationships will be blamed by people, because the victim is considered unable to comply with the normative expectations of society, as a 'good woman'. This 'failure' of the victim to fulfill the expectations of society becomes the justification for, or approval of, the incident of the rape committed upon her.

The attribution of fault to the victim is brought about by someone being considered to have contributed to the occurrence of violence (Bryant \& Spencer, 2003). They discovered that men tend to attribute fault to the victim, in the context of domestic violence (DV). In addition, they discovered that experience witnessing violence, and also gender, contribute to the attribution of fault to the victim.

Violence in interpersonal relationships is normally justified by males. This emerges because of the contribution of the theory of Gender Roles (Shen, Chiu, $\&$ Gao, 2012). Gender roles are male and female behaviors which are in line with social constructs concerning masculinity and femininity (Mahalik et al., 1999 as cited in Miville, 2013). Males tend to have traditional views of gender roles concerning women, so that males tend more to be of the view that the use of violence in relationships can be justified when the females transgress their gender roles (Eigenberg \& Policastro, 2016).

Gender is one of the most basic bases of the interpretation of human perception (Nelson, 2006). This current research also looked at the gender differences of the participants, and also the type of violence experienced by victims of relationship violence. Gender and beliefs concerning traditional gender roles may be predictors of perceptions concerning victims of violence. The social environment expects males to be dominant, in charge, and sexually aggressive, but expect females to act conversely (Yamawaki, 2007). Gender differences in the attribution of blame to the vic- tim were discovered in the research by Yamawaki, Ostenson, and Brown (2009). Males tended more to attribute blame to the victim, compared to the tendencies of females. This is also in accord with the research of Sylaska and Waters (2004 as cited in Mendoza, 2016), which found that male participants tended to place the attribution of fault upon the victim. Mendoza (2015) also discovered similarly, that males tended to attribute fault to the victim, when the victim is considered to have provoked the situation (for instance, by screaming). Males tended to see the victim as the one who is responsible for an incident of violence occurring, and to ignore violent situations.

Regarding the gender factor, it is indicated that striking one's partner, taking revenge, and showing anger, can be justified if the person concerned is betrayed by his partner. A female who is betrayed has the right to strike her partner, and this reflects the perception that aggression, particularly physical aggression by females, is acceptable to society, so males feel justified in striking or taking revenge, if betrayed. This indicates that males are more able to accept the occurrence of physical and psychological aggression in relationships (Forbes et al., 2005).

The level of seriousness of the violence experienced by the victim is known to be a predictor of the perception of, and response to, a person who is the victim of violence. Women in America consider physical violence to be the most serious kind, compared to other types (Mendoza, 2016; Peek-Asa et al., 2002). Capezza and Arriaga (2008) who state that perpetrators who commit physical violence will be viewed negatively by an observer, meaning the observer will possibly have a positive view of the victim of violence, whilst observers tend to consider the behavior of the perpetration of psychological violence as an activity which is unacceptable. This is possibly because observers tend more to attribute the responsibility for psychological violence to the victim.

This experiment was aimed at obtaining empirical evidence related to ambivalent sexism, and the attribution of fault to the victim in perceptions regarding victims of relationship violence (RV). The research is hoped to be able to be of benefit, which is in helping to develop and enlarge experimentation into relationship violence, and to make contributions to research into relationship violence, particularly in the discussion of ambivalent sexism and the attribution of fault to victims of relationship violence. Besides this, the research is hoped to become a reference in predicting ambivalent sexism and the attribution of fault to the victim, regarding perceptions concerning victims 
of relationship violence. From the results of this research, it is hoped to be able to inspire readers to conduct deeper studies concerning ambivalent sexism, the attribution of blame to the victims, and perceptions regarding relationship violence.

In this study, the researchers were interested to know whether ambivalent sexism and the attribution of blame to the victim can predict perceptions regarding victims of violence. Besides this, the researchers also considered the factors of the gender of the subjects, and the type of violence, as matters which could predict perceptions about victims of relationship violence. They used a sample of adolescents, particularly those aged 15 to 22 years, because at these ages adolescents are developing social relationships, such as attraction to the opposite sex, through relations which are more than merely friendship, or which may be termed 'relationships', where, in fact, violence occurs not only in the domestic domain, such as domestic violence, but occurs also within the context of relationships.

This research tested hypotheses concerning the association between ambivalent sexism, attribution of fault to the victim, and perceptions concerning the victims of relationship violence, and additionally the associations between gender type and type of violence, and perceptions about victims of relationship violence (RV). Thus, the research involves hypotheses are as follows:

Hypothesis 1: Ambivalent sexism and the attribution of fault to the victims are able to predict perceptions about the victims of RV.

Hypothesis 2: There are differences in attitudes of ambivalent sexism, the attribution of fault to the victim, and perceptions about the victim, if viewed from [perspectives of] gender factors and types of violence.

Hypothesis 3: Gender can predict perceptions about the victims of relationship violence.

Hypothesis 4: The type of violence can predict perceptions about the victims of relationship violence.

\section{Method}

\section{Participants}

The people who became the subjects of this research were adolescents, aged between 16 and 22 years, undergoing schooling at Senior High School level. The researchers chose adolescents for the sample, with the assumption that were able to act autonomously, and had the freedom systematically to evaluate their own situation and that of the environment, as they were at a formal operationally cognitive stage (Santrock, 2011). Adolescents also have the job of developing relationships with friends of the same age, both of the same gender and of the opposite, and readying them-selves for marriage and having a family.

This research also used a sample of Senior High School students, ranging in age from 14 to 22 years $(M=16.44 ; S D=1.242)$ in Sidoarjo, East Java. This region was selected because, based upon annual reports obtained from the Agency for the Empowerment of Women and for Family Planning (Badan Pemberdayaan Masyarakat Perempuan dan Keluarga Berencana - BPMPKB) in Sidoarjo District, eight cases of relationship violence were revealed in 2015, then in 2016 and 2017 there was one case recorded each year. Although the number of cases was small, based upon BPMPKB data, cases of relationship violence are still occurring in Sidoarjo every year.

In this research, there were dissimilar numbers of male and female students. The number of female subjects was $159(61.9 \%)$, whilst the number of males was $98(38.1 \%)$. Most of the subjects were Muslim (96.7\%). The highest educational level of the subjects was Junior High School, at 100\%. In

Table 1

Subject Profiles Based upon

Demographic Characteristics

\begin{tabular}{|c|c|c|}
\hline Demographic Characteristics & $N$ & $\%$ \\
\hline \multicolumn{3}{|l|}{$\overline{\operatorname{Sex}}$} \\
\hline Female & 159 & 61.9 \\
\hline Male & 98 & 38.1 \\
\hline \multicolumn{3}{|l|}{ Religion } \\
\hline Muslim & 248 & 96.5 \\
\hline Protestant* & 7 & 2.7 \\
\hline Catholic & 1 & 0.4 \\
\hline Hindu & 1 & 0.4 \\
\hline Buddhist & - & 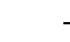 \\
\hline \multicolumn{3}{|l|}{ Highest Education Level } \\
\hline Primary & - & 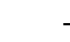 \\
\hline Junior High & 257 & 100 \\
\hline Senior High/Tech. High & - & - \\
\hline Tertiary Institution & - & - \\
\hline \multicolumn{3}{|l|}{ Type of Vignette } \\
\hline Physical Violence & 123 & 47.9 \\
\hline Psychological Violence & 134 & 52.1 \\
\hline
\end{tabular}


the research there were two sets of vignettes given, (Set 1 with illustrations of females who, it was explained, had suffered physical violence, whilst Set 2 was of females who had suffered psychological violence). The number of subjects who filled in a vignette concerning physical violence was 123 persons, whilst the number who filled in vignettes concerning psychological violence was 134 people. Demographic data shown in Table 1.

\section{Research Design}

This was explorative research to explain the connections between independent variables and dependent variables. The independent variables in the research were ambivalent sexism, consisting of benevolent sexism and hostile sexism, and the attribution of fault to the victim, whilst the dependent variable was perceptions about victims of relationship violence. The type of research used in this study was of the quantitative method type. The research utilized a survey, in the form of a questionnaire, for the data collection.

\section{Measurement Instruments}

Ambivalent sexism. Hostile and benevolent sexism were measured using a Likert scale, as compiled by Glick and Fiske (1996) utilizing the Ambivalent Sexism Inventory (ASI), as improved by Mikolajczak and Pietrzak (2015) to become the Extended Ambivalent Sexism Inventory (EASI). The ASI measures attitudes towards women, generally via two patriarchal attitudes which occur jointly, these being Hostile Sexism (11 items) and Benevolent Sexism (11 items) with a 7-point Likert-type point scale $(1=$ 'greatly disagree' through to $7=$ 'greatly agree'). Benevolent sexism admires or expresses sympathy towards women in their traditional roles (for instance: 'Real women must always appear beautiful to the eye'.), and hostile sexism shows an antagonistic attitude towards women seen as transgressing their traditional roles (for example: 'Women who show a good attitude to men only when they want something'). The EASI has a total of 25 items. The reliability value of this research was $\alpha=.763$, with reliability in the hostile sexism dimension being $\alpha=.632$. The research also used factor analysis, utilizing varimax rotation, which later on elicited eight components with an eigenvalue greater than 1 , and the ability to explain $60.71 \%$ of the variant total. The research then used extraction, in line with the original scale dimensions. The results of factor analysis were that four components were able to explain $42.39 \%$ of the variant total.

Several examples of the valid scale points: (1) 'Women have a good attitude to men only when they want something' (with a component matrix of 0.71 ); (2) Neatness and elegance are essentials for femininity (with a component matrix of 0.77); (3) Women have a moral sensibility which is much better than that of males (with a component matrix of 0.76 ).

Attribution of fault to the victim. The instrument used to measure this variable was the Domestic Violence Blame Scale (DVBS) developed by PetreticJackson et al., (1994), the context of which has been brought into line with relationship violence. Within this scale there are four sub-scales, which measure the intensity of the attitudes of respondents towards the blaming of the victim, the situation, society, and the perpetrator, in the context of relationship violence. Respondents were requested to indicate their agreement with the statements in the six-point scale $(1=$ 'greatly disagree', $6=$ 'greatly agree'). The items used for analysis in the research were only those on the victim sub-scale (for example: 'It is the woman who provokes relationship violence'). In this research, the DVBS scale had a reliability of $\alpha=.699$. Regarding the dimension of reliability of the Attribution of Blame to the Victim (ABTV) scale, the reliability values were $\alpha=0.696$. The factor analysis using varimax rotation indicated seven components having an eigenvalue greater than 1 , and the ability to explain $60.2 \%$ of the variant total. Researchers extracted 23 items from the DVBS scale, using a number of initial dimensions from that scale, i.e., four dimensions. The results of factor analysis showed these four components were capable of explaining $43.82 \%$ of the variant total.

Several examples of the valid scales: (1) Relationship violence is a product of a way of thinking, wherein women are regarded by society as property (with a component matrix of 0.64 ); (2) It is women who provoke relationship violence (with a component matrix of 0.68); (3) Relationship violence possibly occurs in couples whose interpersonal relations are poor (with a component matrix of 0.70 ).

Perceptions about the victims of relationship violence. Measurement instrument for perceptions about the victims of relationship violence were developed and used in this research by utilizing narrations, or written vignettes, containing stories of relationship violence, and also photographs of relationship violence. With the aim of manipulation, the research created two vignettes of scenarios which were given to the subjects, i.e., a vignette with the photos of women who 
had suffered physical violence from their partners and a vignette with photos of women who had suffered psychological violence from their partners. The vignettes employed had consistent and controllable backgrounds. Participants were requested to evaluate the characters of the victims, based on 14 characteristics (goodness, independence, care for others, cleverness, responsibility, self-confidence, good female characteristics, modernity, diligence, deference, warmth, loyalty, traditional qualities and laziness), using a fourpoint Likert-style scale ( $1=$ 'greatly disagree', up to $4=$ 'greatly agree'. The data was processed using factor analysis, and two factors were discovered, i.e., traditional and non-traditional perceptions. The results of initial factor analysis using varimax rotation showed there were five components having an eigenvalue greater than 1, and capable of explaining $59.64 \%$ of variant totals. The five components were the results of the extraction of 14 items in the testing. Thereafter, the researchers carried out further extractions, to pro-duce two components. The results of factor analysis were two components in line with the initial component, and the results were capable of explaining $41.11 \%$ of the variant totals.

Several examples of the valid scale points: (1) Loyalty (with a component matrix of 0.72 ); (2) Caring (with a component matrix of 0.63 ); (3) Traditionalism (reversed) (with a component matrix of - 0.75).

\section{Data Analysis}

The data analysis used in testing the hypotheses of this research was multivariate and regression analysis. The data analysis used in testing the hypotheses was multivariate regression analysis and hierarchical regression. Regression analysis has the aim of determining influence, or predicting free variables as compared to the tied variables. The free variables used in multivariate regression number more than one. The technique of regression was used to test the significance and intensity of Hostile Sexism, Benevolent Sexism and the Attribution of Fault to the Victim, as well as the socio-demography and the type of violence, against the perceptions of the victims of relationship violence.

\section{Results}

\section{Descriptive}

On the average, the respondents indicated an attitude disavowing violent sexism, and somewhat supporting benevolent sexism (Table 2), whilst showing an attitude in disagreement with the Attribution of Fault to the Victim $(M=2.59, S D=0.65)$. In the research, it was indicated that the respondents had the perception that the victims presented were traditional females $(M=2.69, S D=0.26)$.

Because the testing of data normality initially showed two variables to have an abnormal distribution, the researchers made a reduction in data, by eradicating outliers The researchers eradicated 32 outliers, leaving data from 257 subjects. After that, the researchers again conducted normality testing and a visual inspection, finding that the data in the research has a normal distribution of data, based upon the results of KolmogorovSmirnov testing, and histogram inspection, so that the analysis used in the following stage was parametric analysis. Homogeneity testing was also conducted, using the Varians Levene homogeneity test, whereby it was discovered that two sets of vignette groups had the same variance, but were not identical in several other socio-demographic groups.

Significant differences were found regarding gender and vignette type (Table 3 ). In the gender groups, it was shown that there were differences between males and females regarding the variables measured. Males had a higher tendency towards an attitude of ambivalent sexism, particularly regarding hostile sexism $(M=4.03 ; S D=0.91)$, and in attributing blame to the victim $(M=2.82 ; S D=0.60)$, whereas in the testing of differences, based upon the type of vignette received, the subjects also indicated the existence of a difference.

Table 2

Descriptive Scale Scores

\begin{tabular}{lccccccc}
\hline \multicolumn{1}{c}{ Variable } & Scale & Mean & SD & Min. & Max. & $\begin{array}{c}\text { Skewedness } \\
(\text { SE) }\end{array}$ & Kurtosis (SE) \\
\hline Hostile Sexism & $1-7$ & 3.45 & 0.93 & 1.50 & 5.80 & $0.31(0.15)$ & $-0.44(0.30)$ \\
Benevolent Sexism & $1-7$ & 4.99 & 0.59 & 3.40 & 6.33 & $-0.08(0.15)$ & $-0.44(0.30)$ \\
Attribution of Blame of the Victim & $1-6$ & 2.58 & 0.65 & 1.00 & 4.14 & $-0.10(0.15)$ & $-0.47(0.30)$ \\
Perception Concerning Victim & $1-4$ & 2.69 & 0.26 & 2.00 & 3.36 & $0.08(0.15)$ & $0.27(0.30)$ \\
\hline
\end{tabular}

Note. $S D=$ Standard Deviation, $S E=$ Standard Error 
Table 3

Results of one-way Analysis of Variance (ANOVA) Testing

\begin{tabular}{|c|c|c|c|c|c|c|c|c|c|c|c|c|c|}
\hline & & \multicolumn{3}{|c|}{$\mathrm{PCV}$} & \multicolumn{3}{|c|}{ HS } & \multicolumn{3}{|c|}{$\overline{B S}$} & \multicolumn{3}{|c|}{ ABTV } \\
\hline & & Mean & $S D$ & Sig. & Mean & $S D$ & Sig. & Mean & $S D$ & Sig. & Mean & $S D$ & Sig. \\
\hline \multirow[t]{3}{*}{$\overline{\text { Gender }}$} & Male & 2.68 & 0.31 & & 4.03 & 0.91 & & 5.01 & 0.91 & & 2.82 & 0.60 & \\
\hline & Female & 2.69 & 0.23 & .72 & 3.10 & 0.76 & .00 & 4.98 & 0.76 & .77 & 2.43 & 0.64 & .00 \\
\hline & Total & 2.69 & 0.26 & & 3.45 & 0.93 & & 4.99 & 0.93 & & 2.58 & 0.65 & \\
\hline \multirow[t]{3}{*}{$\begin{array}{l}\text { Vignette } \\
\text { Type }\end{array}$} & $\begin{array}{l}\text { Physical } \\
\text { Violence }\end{array}$ & 2.64 & 0.25 & & 3.29 & 0.88 & & 4.87 & 0.60 & & 2.51 & 0.71 & \\
\hline & $\begin{array}{l}\text { Psychologica } \\
\text { Violence }\end{array}$ & 2.73 & 0.27 & .01 & 3.60 & 0.95 & .00 & 5.10 & 0.57 & .00 & 2.64 & 0.59 & .10 \\
\hline & Total & 2.69 & 0.26 & & 3.45 & 0.93 & & 4.99 & 0.59 & & 2.58 & 0.65 & \\
\hline
\end{tabular}

Note. $\mathrm{PCV}=$ Perceptions Concerning the Victim; HS = Hostile Sexism; BS = Benevolent Sexism; ABTV = Attribution of Blame to the Victim;

$S D=$ Standard Deviation; Sig. $=$ Significance. Significant if $p<.05$.

The types of vignettes which concerned psychological violence had a higher tendency towards a more positive perception of the victims of relationship violence $(M=2.73 ; S D=0.27)$, attitudes of hostile $\operatorname{sexism}(M$ $=3.60 ; S D=0.95)$, and benevolent sexist attitudes $(M$ $=5.10 ; S D=0.57)$.

\section{Correlation Testing}

Table 4 shows a significant connection between the benevolent sexism variable and the perception of the victim of relationship violence, with a positive direction to the connection. However, the correlation coefficient values variable was in the weak category, being 0.18. This meant that the higher the benevolent sexism value for an individual, the more positive the perception of the victim of relationship violence, particularly in the matter of the perception about traditional females.

\section{Regression Testing}

The testing was of multivariate regression analysis, against the principle tied and free variables (HS, BS, and ABTV) shown in Table 5. From the results of the multivariate regression, it was found that it was only the BS variable which had any significant prediction value against the $\mathrm{PCV}$, with an $R^{2}$ value of 0.03 , meaning it was able to explain $3 \%$ of the PCV $\mathrm{RV}$ variants, with prediction strength of $18 \%$ for PCV RV.

Hostile sexism has a negative prediction towards relationship violence (RV), meaning that the less is the hostile sexism, the greater is the relationship violence, and this is the same as the ABTV variable, compared to relationship violence. Then the benevolent sexism (BS) variable has a positive prediction, meaning that the greater the BS, the greater also the percep-
Table 4

Results of Correlation Testing

\begin{tabular}{|c|c|c|c|c|}
\hline Variable & 1 & 2 & 3 & 4 \\
\hline 1. HS & - & & & \\
\hline 2. $\mathrm{BS}$ & $.25 * *$ & - & & \\
\hline 3. ABTV & $.39 * *$ & .45 & - & \\
\hline 4. PCV & .03 & $.18 * *$ & -.01 & - \\
\hline
\end{tabular}

Table 5

Results of Multivariate Regression Testing

\begin{tabular}{|c|c|c|c|c|c|}
\hline & $B$ & $B S E$ & $\beta$ & $t$ & $p$ \\
\hline Konstanta & 2.28 & 0.15 & - & 15.01 & .00 \\
\hline HS & -0.00 & 0.02 & -0.00 & -0.04 & .96 \\
\hline BS & 0.08 & 0.02 & 0.19 & 2.98 & .00 \\
\hline ABTV & -0.00 & 0.02 & -0.01 & -0.26 & .79 \\
\hline
\end{tabular}

tion concerning the victim (PCV). This means that the $\mathrm{BS}$ variable is the strongest predictor of perceptions concerning the victim. An individual with high BS values will have a positive perception of the victim of relationship violence. Additionally, the researchers conducted hierarchical regression analysis on the principle variables, followed by the additional variables, i.e., the variables of the gender of the subject, and the variable of the type of violence.

From hierarchical regression testing (see Table 6), it is known that benevolent sexism (BS) and psychological violence contribute to perceptions about the victim of relationship violence (RV), whilst no contribution was found from gender. The BS variable is capable of a positive prediction, meaning the greater the BS, the greater also the PCV RV. An individual with very high $\mathrm{BS}$ values will have the perception 
Table 6

Results of the Testing of Hierarchical Regression of Demographic Character, Type of Violence and BS on Relationship Violence

\begin{tabular}{clcccccc}
\hline Model & $B$ & $B S E$ & $\beta$ & $R^{2}$ & $\Delta R^{2}$ & $p$ \\
\hline \multirow{2}{*}{1} & Kontanta & 2.26 & 0.14 & - & & .00 \\
& BS & 0.08 & 0.02 & 0.18 & .03 & - & .00 \\
& & & & & & .00 \\
& Konstanta & 2.28 & 0.13 & - & & & .00 \\
2 & BS & 0.08 & 0.02 & 0.18 & .04 & .01 & .00 \\
& Type of Violence & 0.07 & 0.03 & 0.13 & & \\
\hline
\end{tabular}

Note. $\quad$ Dependent variable $=$ PCV. PCV $=$ Perception Concerning Victim, BS $=$ Benevolent Sexism Physical Violence $=0$, Psychological Violence $=1$, $B=$ Non-standardised regression coefficient, $S E=$ Standard Error, $\beta=$ beta, significant if $p<.05$.

that the victim of RV is a traditional woman. Psychological violence can lead to a positive prediction, meaning when a victim of RV suffers psychological violence, the victim will be viewed as a traditional female.

\section{Discussion}

This research has shown that it is only ambivalent sexism, particularly benevolent sexism, which is able to predict perceptions about the victims of RV, whilst with hostile sexism and attribution of fault to the victim; it is a variable which is a predictor of perceptions about such victims. It was found in this research that there is a connection between benevolent sexism and perceptions concerning the victim. An individual having a high degree of benevolent sexism will demonstrate the perception that a victim of RV is a traditional female. The research also discovered that benevolent sexism is a predictor variable of the perception that a victim of $\mathrm{RV}$ is a traditional female. This in line with the discoveries of Gaunt (2013), i.e., that benevolent sexism predicts a positive perception of a woman raising children, whilst HS has a greater connection with the negative perception of someone who is transgressing her gender role. An individual who has benevolent sexism will view positively a female who does not transgress her gender role.

A woman who transgresses her gender role, such as a career woman, is viewed negatively by someone who has hostile sexism, because someone with hostile sexism will tend to view her as a woman who threatens his male role. When a female transgresses traditional gender roles, she will tend to be categorized as a member of a group which is disliked, and which needs no protection from males (Glick \& Fiske, 2001; Sakalh, 2001; Yakushko, 2005; Yamawaki, Ostenson, \& Brown,
2009), whilst a woman who is rearing children is viewed positively by someone with benevolent sexism, because she has not transgressed her gender role. This indicates that a social attitude is not generally restricted to certain social categories. Implications of sexist attitudes are not restricted by evaluations of social category, but play a role in determining individual perceptions, which may describe the family environment and daily life (Gaunt, 2013).

Differences in ambivalent sexism attitudes, the attribution of blame to the victim, reviewed from the factors of gender and type of violence, have also been discovered in this research. The research showed the existence of gender differences in hostile sexism. Males tended to have a traditional gender view towards females (Eigenberg \& Policastro, 2016). Besides this, regarding gender differences in the attribution of blame to the victim, males in this research tended to attribute blame to the victim. These discoveries were in line with those of Yamawaki, Ostenson, and Brown (2009), who discovered gender differences in the attribution of blame to the victim. Males had a greater tendency to attribute blame to victims than do females. Males tend to see victims as figures that are responsible for the incidents of violence which befall them (Mendoza, 2016; Sylaska \& Waters, 2004). They also tend to attribute blame to the victim when the victim provokes, or does something to trigger off, violence (Mendoza, 2016).

Furthermore, in the research, regarding the basis of the type of violence, there were other differences discovered. These differences were discovered with psychological violence, in regard to the perception that the victim was a traditional woman, to hostile sexism and to benevolent sexism. The discoveries differed from those of Peek-Asa et al., (2002 as cited in Mendoza, 2016) which explained that the level of seriousness of violence was able to predict the response of the in- 
dividual towards the victim. Respondents in the research by Peek-Asa et al., (2002 as cited in Mendoza, 2016) tended to see physical violence as the most serious type of incident, whilst gender is known not to be capable of predicting perceptions regarding the victims of relationship violence (RV).

These discoveries differed from the opinion of Nelson (2006) that gender is one of the bases of the most basic interpretation of human perception, which can predict the interpretation by observers of information gathered from the environment. In this research, gender was found not to be able to predict the perception that the victim of RV was a traditional woman.

Apart from benevolent sexism, the type of violence was also a predictor of the perception that the victim of RV was a traditional woman. Gaunt (2013) also said that someone displaying benevolent sexism would view more positively the female victim of violence, who was considered not to have transgressed her gender role.

Incidence of psychological violence was able to predict the perception that the victim of RV was a traditional woman. The victim of psychological violence was viewed positively by respondents. This could be because of convictions regarding gender, held by respondents. (Capezza \& Arriaga, 2008) explained that psychological violence committed by the perpetrator was an unacceptable thing, but was not viewed negatively. This was possibly because observers more attributed the blame to the victim, such as by considering that it was the victim who provoked the incident. This indicates that perception of the perpetrator of violence is predicted not only by the actions of the victim and the situation. Observers tended to evaluate physical violence as the most serious type, compared to psychological violence, because psychological violence does not produce any visible danger. When observers are of the opinion that the victim has transgressed her responsibilities, then the said victim tends to be viewed negatively. Although these discoveries of Capezza and Arriaga (2008) discussed the perceptions concerning the perpetrator of violence, the explanations can somewhat explain why individuals view positively the recipients of psychological violence. Respondents in this research were possibly convinced that the victims had transgressed their responsibilities only somewhat, so that the victim suffered only psychological violence from her paramour. Thus the respondents tended to tolerate the small errors made by the victim, and still held positive views of her.

\section{Conclusion}

The factors contributing to perceptions concerning victims are benevolent sexism and type of violence. The higher the benevolent sexist attitude held by an individual, the more positive the perceptions held by that individual towards the victim of RV. Individuals holding a high degree of benevolent sexism will view the victim of RV as a traditional woman, who has not transgressed her traditional role. Furthermore, psychological violence is capable of predicting the perceptions held by an individual towards the victim of RV, that she is a traditional woman. These things indicate that when the victim does not transgress her gender role, she will be perceived positively by that individual.

\section{Expressions of Appreciation}

This article was presented at the national Scientific Convention of the Indonesian Psychology Association (Temu Ilmiah Himpunan Psikologi Indonesia), in Bandung, East Java, on September 7 and 8, 2018. The researchers also express thanks to the Institute for Development of Scientific Publications of the Muhammadiyah University, Surakarta (Lembaga Pengembangan Publikasi Ilmiah - Universitas Muhammadiyah Surakarta - LPPI UMS), for the opportunity to participate in the activities of the National Scientific Writing Clinic (Klinik Penulisan Artikel Ilmiah Nasional) of 2018, in Solo, Central Java.

\section{Limitations}

This research is not free from shortcomings, which are to be found in this research, the first being the difficulty of obtaining literature regarding ambivalent sexism (AS) and Attribution of Blame to the Victim (ABTV), particularly in the context of relationship violence (RV), which is still not readily available in Indonesia, so that in this research, the literature used was largely from foreign sources. Secondly, difficulty was also encountered in obtaining literature concerning the influence from the type of violence, regarding perceptions regarding victims. Thirdly, the measurement instruments used in the research were in the form of 'self-reporting', which enabled the emergence of bias, such as ambiguity and misinterpretation, in responses from the participants. For this reason, future research will need to give consideration, when utilizing 'selfreporting', to minimalizing the presence of bias, to obviate the possibility of the occurrence of misinterpretation in responses from participants. 


\section{References}

Abrams, D., Viki, T., Masser, B., \& Bohner, G. (2003). Perceptions of stranger and acquintance rape: The role of benevolent and hostile sexism in victim blame and rape proclivity. Journal of Personality and Social Psychology, 84, 111-125. https://doi.org/10.10 37/0022-3514.84.1.111

Bidang Pemberdayaan Perempuan dan Perlindungan Anak. (2018). Data Kasus Kekerasan Tahun 2015, 2016, dan 2017. Sidoarjo: BPMPKB Sidoarjo.

Capezza, N. M, \& Arriaga, X, B. (2008). Why do people blame victims of abuse? The role of stereotypes of women on perceptions of blame. Journal of Sex Roles, 59, 839-850. https://doi.org/10.1007/s11199008-9488-1

Capezza, N. M. \& Arriaga, X. B. (2008). You can degrade but you can't hit: Differences in perceptions of psychological versus physical aggression. Journal of Social and Personal Relationships, 25, 225245. https://doi.org/10.1177/0265407507087957

Eigenberg, H., \& Policastro, C. (2016). Blaming victims in cases of interpersonal violence: Attitudes associated with assigning blame to female victims. Women \& Criminal Justice, 26(1), 37-54. https:// doi.org/10.1080/08974454.2014.997417

Fiske, S., Cuddy, A., Xu, J., \& Glick, P. (2002). A model of (often mixed) stereotype content: Competence and warmth respectively follow from perceived status and competition. Journal of Personality and Social Psychology, 82, 878-902. https://doi.org/10.10 37/0022-3514.82.6.878

Forbes, G. B., Jobe, R. L., White, K. B., Bloesch, E., \& Adam-Curtis, L. E. (2005). Perceptions of dating violence following a sexual or nonsexual betrayal of trust; Effect of gender, sexism, acceptance of rape myth, and vengeance motivation. Sex Roles, 52, Nos, 3/4. https://doi.org/10.1007/s11199-005$1292-6$

Gaunt, R. (2013). Ambivalent sexism and perception of men and women who violate gendered family roles. Community, Work \& Family, 16, 401-416. https://doi.org/10.1080/13668803.2013.779231

Glick, P., \& Fiske, S. (1996). The Ambivalent Sexism Inventory: Differentiating hostile and benevolent sexism. Journal of Personality and Social Psychology, 70, 491-512. https://doi.org/10.1037/00223514.70.3.491

Lembar Fakta Catatan Tahunan (Catahu) Komnas Perempuan. (2014). Kekerasan terhadap perempuan: Negara segera putus impunitas pelaku. Accessed through: http://www.komnasperempuan.go.id/wp
content/uploads/2015/03/Lembar-Fakta-CatatanTahunan-CATAHU-Komnas-Perempuan-Tahun2014.pdf on 9 December, 2016.

Lembar Fakta Catatan Tahunan (Catahu) Komnas Perempuan. (2016). Kekerasan terhadap perempuan meluas: Mendesak negara hadir hentikan kekerasan terhadap perempuan di ranah domestik, komunitas, dan negara. Accessed through: http://www.komnas perempuan.go.id/wpcontent/uploads/2016/03/Le mbar-Fakta-Catatan-Tahunan-_CATAHU_-Kom nas-Perempuan-2016.pdf on 27 October, 2016.

Lembar Fakta Catatan Tahunan (Catahu) Komnas Perempuan. (2017). Labirin kekerasan terhadap perempuan: Dari gang rape hingga femicide, alarm bagi negara untuk bertindak tepat. Accessed from: https://www.komnasperempuan.go.id/file/pdf_fil e/2017\%20Siaran\%20Pers/Lembar\%20Fakta\%20 Catahu\%202017.pdf on 25 January, 2018.

Mendoza, J. (2016). Dating violence myth acceptance and victim blaming among college students: Does gender matter?. [Thesis]. California State University, San Bernardino.

Mikolajczak, M., \& Pietrzak, J. (2015). Ambivalent sexism and religion: Connected through values. Sex Roles, 70, 387-399. https://doi.org/10.1007/s11199014-0379-3

Miville, M. L. (2013). Multicultural gender roles. Canada: John Wiley \& Sons, Inc.

Nelson, T. (2006). The psychology of prejudice. Boston: Pearson Education.

Petretic-Jackson, P., Sandberg, G., \& Jackson, T. (1994). The domestic violence blame scale. In L. Vande Creek, S. Knapp, \& T. Jackson, Innovations in clinical practice (pp. 265-278). Saratosa: Professional Resource Press/ Professional Resource Exchange.

Santrock, J. (2011). Life-span development, Edition 13. New York: McGraw Hill.

Schoellkopf, J. (2012). Victim blaming: A new term for an old trend. Lesbian Gay Bisexual Trangender Queer Center. Paper 33. Accessed from: http://di gitalcommons.uri.edu/cgi/viewcontent.cgi?article $=1032 \&$ context $=$ glbtc on 23 August, 2017.

Shen, A. C., Chiu, M. Y., Gao, J. (2012). Predictors of dating violence among Chinese adolescents: The role of gender role beliefs and justification of violence. Journal of Interpersonal Violence, 27. https:// doi.org/10.1177/0886260511424497

Waltermaurer, E. (2012). Public justification of intimate partner violence: A review of the literature. Trauma, Violence, \& Abuse, 13, 167-175. https:// doi.org/10.1177/1524838012447699

Wekerle, C., \& Wolfe, D. A. (1999). Dating violence 
in mid-adolescence: Theory, significance, and emerging prevention initiatives. Clinical Psychology Review, 19. https://doi.org/10.1016/S0272-7358(98) 00091-9

Witte, T., Schroeder, D., \& Lohr, J. (2006). Blame for intimate partner violence: An attributional analysis. Journal of Social and Clinical Psychology, 25, 647667. https://doi.org/ 10.1521/jscp.2006.25.6.647

World Health Organization (WHO). (2017). Violence against women: Intimate partner and sexual violence against women. Accessed from: http://www.who. int/mediacentre/factsheets/fs239/en/ on 23 March, 2018.

Yamawaki, N. (2007). Rape perception and the function of ambivalent sexism and gender role traditi- onality. Journal of Interpersonal Violence, 22. https:// doi.org/10.1177/0886260506297210

Yamawaki, N., Ostenson, J., \& Brown, C. R. (2009). The functions of gender role traditionality, ambivalent sexism, injury, and frequency of assault, on domestic violence perception. Violence Against Women, 15, 1126-1142. https://doi.org/10.1177/1077 801209340758

Yamawaki, N., Ochoa-Shipp, M., Pulsipher, C., Harlos, A., \& Swindler, S. (2012). Perception of domestic violence: The effects of domestic violence myths, victim relationship with her abuser, and the decision to return to her abuser. Journal of Interpersonal Violence. 27(16), 3195-3212. https://doi.org/10.11 $77 / 0886260512441253$ 